DOE/EA-0810

\title{
ENVIRONMENTAL ASSESSMENT for the AMMUNITION STORAGE FACILITY at the SAVANNAH RIVER SITE
}

\author{
U. S. DEPARTMENT OF ENERGY \\ SAVANNAH RIVER FIELD OFFICE \\ SAVANNAH RIVER SITE
}




\section{TABLE OF CONTENTS}

SECTION

PAGE

1.0 Need for Action 1

2.0 Proposed Action and Alternatives 1

2.1 Proposed Action 1

2.2 Alternatives to the Proposed Action 2

3.0 Environmental Impacts 2

4.0 Safety Impacts 5

$\begin{array}{lll}5.0 & \text { References } & 6\end{array}$ 


\subsection{Need for Action}

Wackenhut Services, Inc. (WSI) is under contract with the Department of Energy (DOE) to provide security support services for the Savannah River Site (SRS), a DOE national defense facility. The SRS maintains an armed and uniformed protective force that performs patrol, guard, and monitoring activities on site. A safe, secure storage facility is needed for the storage of weapons, small arms ammunition, and explosives that may be used in carrying out such activities. This Environmental Assessment assesses the potential environmental and related safety impacts of constructing a small storage facility to replace the existing facility being used to store these munitions.

Constructing a new storage facility is necessary to enable SRS to meet DOE requirements and any other applicable standards. See, e.g., DOE Orders6430.1A, General Design Criteria; - 5632.7, Protective Forces; - DOE ManualsDOE/TIC 11268, Manual for Prediction of Blast and Fragment Loading for Structures; - DOE/EV 06194-5, and Explosives Safety Manual.

Additionally, this action is needed because the present facility, the Building 217-F vault, does not comply with the above criteria for storage of munitions and explosives, and has been cited with seven occupational safety violations by DOE safety engineers. The most serious noted violations are due to the existing lack of appropriate storage space: munitions stacked directly against masonry walls, weapons stored in the same magazine as the munitions, inoperable ventilation system, inadequate air circulation, and the existence of electrical fans and switchgear within the magazine.

Construction of a new facility would meet the following objectives: eliminate any undue threat to public health and well-being from the continuing storage of these munitions in a building not designed for their storage; and (2) eliminate any undue hazards to SRS employees from their storage. A review of DOE requirements has shown that SRS cannot meet the above criteria for storage of munitions and explosives without replacing the existing storage and constructing this new facility.

\subsection{Proposed Action and Alternatives}

\subsection{Proposed Action}

The proposed action is to replace the existing small arms ammunition and explosive storage facility, the Building $217-\mathrm{F}$ vault, with a new safe, secure munitions stcrage facility that would be constructed on a two acre site adjacent to the southwest comer of B Area on SRS and about three miles from the nearest SRS site boundary. The munitions would be stored in shipping containers within the facility and would include live and blank small arms ammunition (.45 caliber or less), smoke and tear gas grenades, fuses and high explosives (less than 50 pounds). The proposed storage facility would provide three small 500 square-foot, earth covered, corrugated steel, arch-type reinforced concrete ammunition storage magazines and one small 220 square- 
foot weapons storage building (see Figure 1). The three $20 \times 25$ foot magazines would be waterproofed, and separated by and covered by earth.

The facility would be fenced and surrounded by a buffer zone of 250 to 500 feet, with entrances opening away from B Area and facing an earth barricade. The maximum planned munitions storage of the new SRS facility is $177 \mathrm{lbs}$ net explosive weight and $29,000 \mathrm{lbs}$ total physical weight including such things as casings, shipping containers, and pallets. However the facility would be designed to the standard storage capacity of 500,000 lbs net explosive weight, further increasing its safety factors. The proposed cost of this general plant projest is estimated to be approximately $\$ 1.09$ million.

\subsection{Alternatives to the Proposed Action}

One alternative to the proposed action is to take no action. This would result in a failure to meet the above DOE requirements for storage of munitions and explosives and continuing the storage of these munitions in an existing building not designed for their storage. Thus, the no action alternative is not a reasonable alternative to the proposed action.

Another alternative to the proposed action would be to construct the storage facility using aboveground, prefabricated metal structures permanently installed on concrete pads. Under this alternative, two approximately 800 square foot structures and one approximately 600 square foot structure would be constructed of rolled steel and covered on the interior with a non-sparking surface. These structures could be constructed and installed at less cost than the proposed action, but they could not store as many munitions, nor could these unbermed structures afford the safety and protection that the proposed concrete igloo structures would afford. This alternative would require maintaining approximately twice the amount of buffer zone to achieve the same level of safety as the proposed earth-covered concrete design.

An additional alternative to the proposed action would be to construct the new facility at an alternate SRS site. An alternate SRS site would require onsite transportation of the munitions to operations and training facilities at B Area, as the need arose. This would not be as desirable or as efficient as the proposed action of locating the storage facility adjacent to the existing operations and training facilities.

\subsection{Environmental Impacts}

SRS occupies about 199,000 acres in southwestern South Carolina located 17 miles southeast of Augusta, GA (see Figure 2). B-Area is centrally located on SRS and contains administration offices and training facilities, and is surrounded by wooded areas. In addition to B-Area, the SRS site contains other facilities including five nuclear production reactor areas; two chemical separations areas; waste processing, storage, and disposal facilities; and various supporting facilities.

The proposed action would take place in an already cleared, level area adjacent to a previously developed area on SRS. Standard erosion control measures would be implemented during construction. Also during construction, any potential fugitive dust emissions would be minimized by sprinkling or other standard control methods. This would effectively mitigate any impacts to the 

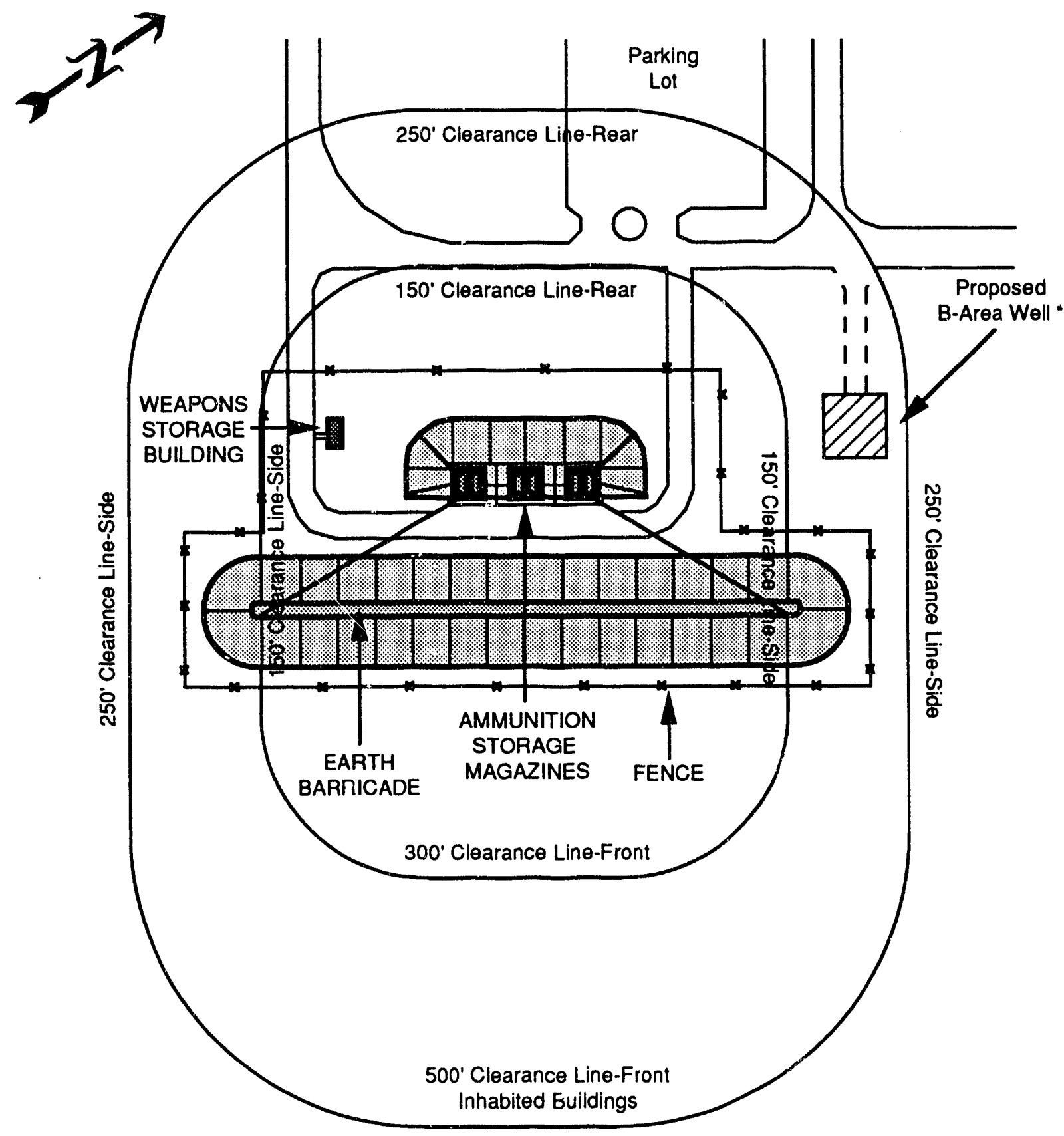

- Proposed B-Area well lies within the setback zone and poses no safety or security concerns because it would be uninhabiteo if built. Well Scale: 1 inch $=50$ feet maintenance access would be coordinated with WSI if built.

Figure 1. Site plan for the Ammunition Storage Facility at the Savannah River Site 


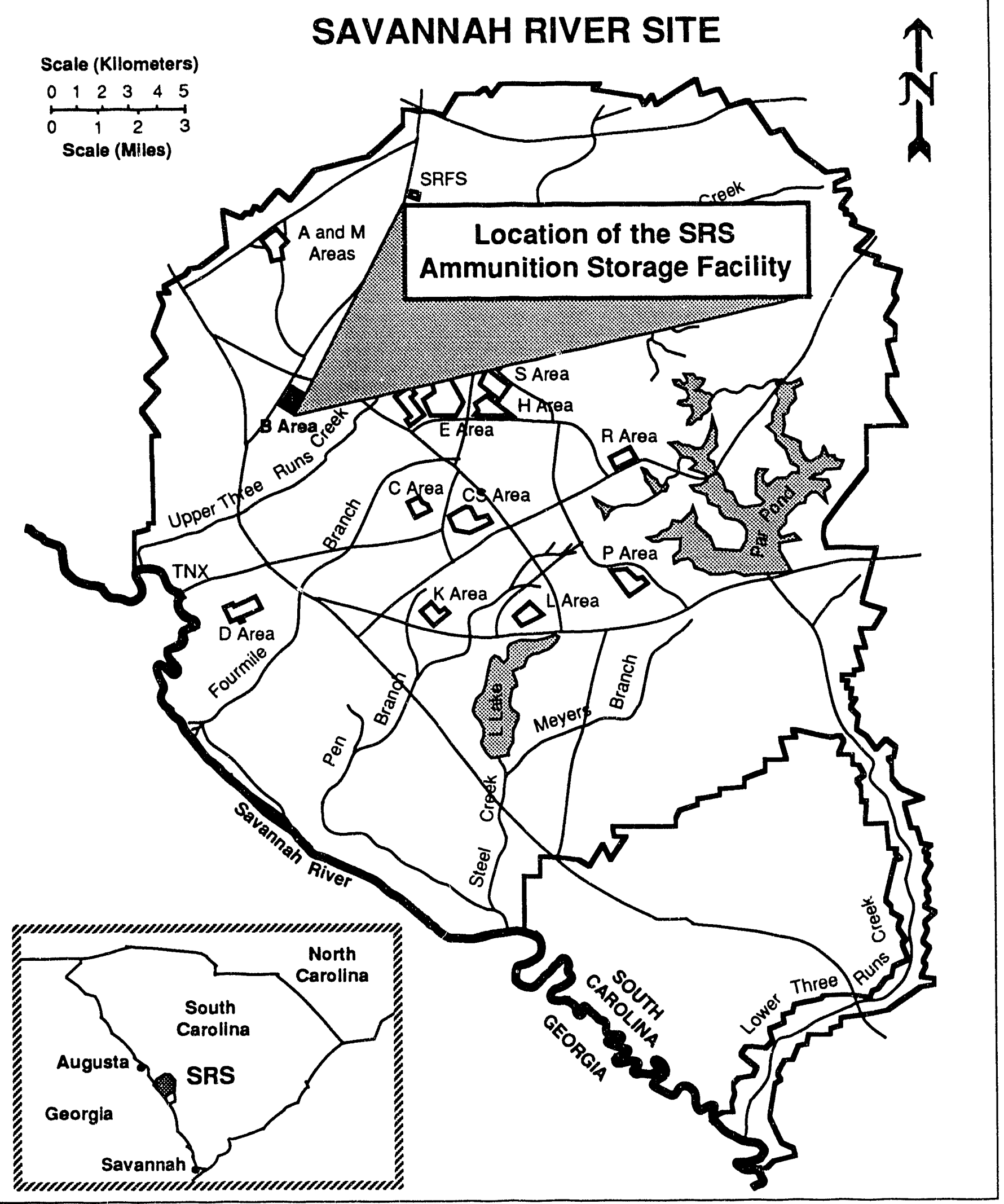

Figure 2. Location of the SRS Ammunition Storage Facility at the Savannah River Site 
surrounding environment. Standard construction materials would be utilized in the facility's construction.

No environmental permits would be required for this action. Approximately $67.500 \mathrm{Kw} \mathrm{Hr} / \mathrm{year}$ of electrical power usage is anticipated. No radioactive materials would be stored in this facility. Replacement munition are ordered as needed and transported to SRS through commercial motor carriers. There would be no air, liquid, or solid releases or emissions subject to regulations from this small storage facility. The proposed two acre facility site has been essentially unused land containing grasses and bushes. No environmentally sensitive areas or natural resources such as historical or archaeological sites, endangered species or their habitats, or wetlands are present and therefore none would be affected.

The Final Environmental Impact Statement for the Continued Operation of K-, L-, and P-Reactors (DOE, 1990) and the most recent socioeconomic survey of the six-county SRS area of influence (NUS, 1990) contain additional information on SRS areas and facilities, and the areas surrounding SRS.

\subsection{Safety Impacts}

The proposed action is the safe, secure storage of closed DOT-approved shipping containers holding ammunition, weapons, and explosives in a proposed small SRS concrete sturage facility. The proposed action would be beneficial with respect to safety since it would reduce the potential hazards resulting from continued use of the existing Building 217-F vault.

The proposed facility would provide a level of protection which would exceed the DOE design high hazard criteria for buildings for natural phenomena. For example, according to the DOE Natural Phenomena Hazards Criteria, the high hazard threshold damage speeds for straight and tornado winds are $137 \mathrm{mph}$ and $185 \mathrm{mph}$, respectively. This means straight winds in excess of $137 \mathrm{mph}$ and tornado winds in excess of $185 \mathrm{mph}$ would cause some facility damage to a normal free standing facility, but very little damage to an earth covered storage facility like the proposed facility.

In addition, the proposed facility design would adhere to strict occupational safety and physical security criteria, and thus mitigate the potential exists for accidental explosion, sabotage, or theft. Additional design features to prevent the occurrence of accidents include steel blast doors, explosion proof fixtures, special ventilation louvers, explosion proof electrical fixtures, smoke detectors and alarms, intrusion alarms, a seven foot fence, and perimeter lighting. The facility would have no permanent personnel and would be sited so that there would be no adjacent facilities that would be affected should an accident occur. Thus, in the unlikely event of an explosion involving all of the stored material, there would be no permanent personnel onsite or any nearby facilities close enough to be affected. 


\section{$5.0 \quad$ References}

Ammann \& Whitney, 1984-87. Structures to Resist the Effects of Accidental Explosions, Volumes I-VI, US Army Armament Research, Development and Engineering Center, New York, New York.

COE (US Army Corps of Engineers) 1990. Functional Performance Requirements for WSI Ammunition Storage Facility, Rev 1, Problem 13-3024, Project S-3596, Savannah River Site, Aiken, South Carolina.

COE (US Army Corps of Engineers) Letter dated April 30, 1992. WSI Ammunition Storage Facility. Project S-3596, Building Category of Protection, Charleston District, Charleston, South Carolina.

DOD ( US Department of Defense), 1984. Manual DOD 6055.9-STD,_Ammunition and Explosives Safety Standards Manual, Washington, DC.

DOE (US Department of Energy) 1990. Final Environmental Impact Statement Continued Operation of K-L L-. and P-Reactors. Savannah River Sit - DOE/EIS0147, Savannah River Operations Office, Aiken, South Carolina.

NUS (NUS Corporation), 1990. Socioeconomic Characteristics of Selected Counties and Communities Adjacent to the Savannah River Site, NUS Report No. 5234, Aiken, South Carolina.

DOE (US Department of Energy) Order-6430.1A, General Design Criteria.

DOE (US Department of Energy) Order- 5632.7, Protective Forces.

DOE (US Department of Energy) Manual-DOE/TIC 11268, Manual for Prediction of Blast and Fragment Loading for Structures.

DOE (US Department of Energy)Manual- DOE/EV 06194-5, Expiosives Safety Manual.

DOA (Department of the Army), Technical Manual 5-1300.

DOA (Department of the Army), Army Regulation 190-11.

OSHA (Occupational Safety \& Health Administration) OSHA Standards-Hazardous Materials. Subpart H. Explosives and Blasting Agents. 29 CFR. 1910.109. 

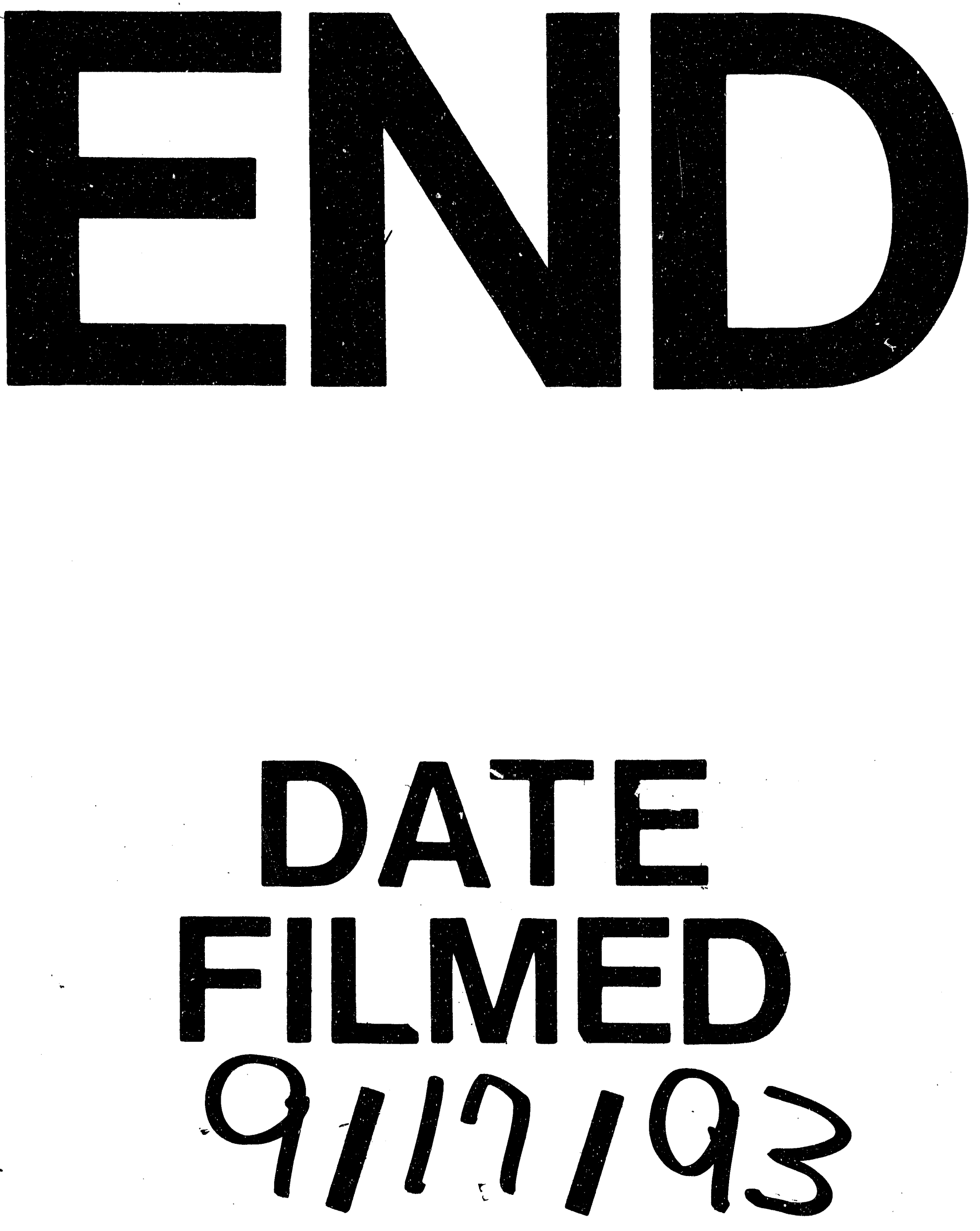

1 
